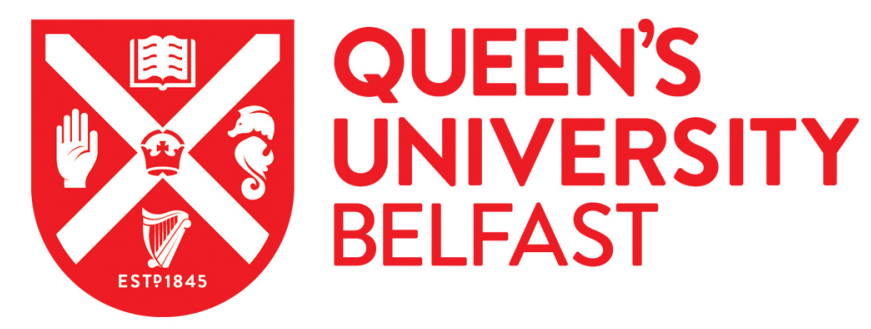

\title{
Effect of high pressure processing on the safety, shelf life and quality of raw milk
}

Stratakos, A. C., Inguglia, E. S., Linton, M., Tollerton, J., Murphy, L., Corcionivoschi, N., Koidis, A., \& Tiwari, B. K. (2019). Effect of high pressure processing on the safety, shelf life and quality of raw milk. Innovative Food Science and Emerging Technologies, 52, 325-333. https://doi.org/10.1016/j.ifset.2019.01.009

Published in:

Innovative Food Science and Emerging Technologies

Document Version:

Peer reviewed version

Queen's University Belfast - Research Portal:

Link to publication record in Queen's University Belfast Research Portal

Publisher rights

(C) 2019 Elsevier Ltd.

This manuscript version is made available under the CC-BY-NC-ND 4.0 license http://creativecommons.org/licenses/by-nc-nd/4.0/,which permits distribution and reproduction for noncommercial purposes, provided the author and source are cited

\section{General rights}

Copyright for the publications made accessible via the Queen's University Belfast Research Portal is retained by the author(s) and / or other copyright owners and it is a condition of accessing these publications that users recognise and abide by the legal requirements associated with these rights.

Take down policy

The Research Portal is Queen's institutional repository that provides access to Queen's research output. Every effort has been made to ensure that content in the Research Portal does not infringe any person's rights, or applicable UK laws. If you discover content in the Research Portal that you believe breaches copyright or violates any law, please contact openaccess@qub.ac.uk. 
EFFECT OF HIGH PRESSURE PROCESSING ON THE SAFETY, SHELF LIFE AND QUALITY OF RAW MILK

Alexandros Ch. Stratakos ${ }^{\mathrm{a}}$, Elena S. Inguglia ${ }^{\mathrm{b}}$, Mark Linton ${ }^{\mathrm{a}}$, Joan Tollerton ${ }^{\mathrm{a}}$, Liam Murphy ${ }^{\mathrm{d}}$, Nicolae Corciononivoschi ${ }^{\mathrm{a}}$, Anastasios Koidis ${ }^{\mathrm{c}^{*}}$, Brijesh K. Tiwari ${ }^{\mathrm{b}}$

a Bacteriology Branch, Veterinary Sciences Division, Agri-Food and Biosciences Institute, 12 Stoney Road, Belfast, BT4 3SD, Northern Ireland, United Kingdom.

b Department of Food Biosciences, Teagasc Food Research Centre, Ashtown, Dublin, 15, Ireland.

c Institute for Global Food Security, Queen's University Belfast, Belfast, Northern Ireland, UK.

${ }^{\mathrm{d}}$ HPP Tolling, FoodCentral, St. Margaret's, Co. Dublin

\section{* Corresponding author}

Dr Anastasios Koidis, Institute for Global Food Security, Queen's University Belfast, Belfast, Northern Ireland, UK. Email: t.koidis@qub.ac.uk,

\section{Keywords}

Raw milk, high pressure, safety, shelf life, colour, stability 


\begin{abstract}
High pressure processing (HPP) was investigated as an alternative to standard raw milk processing. Different pressure levels (400-600 MPa) and exposure times (1-5 min) were tested against artificially inoculated pathogenic E. coli, Salmonella and L. monocytogenes. HPP effectively inactivated bacterial concentration by $5 \log \mathrm{CFU} / \mathrm{ml}$. CFU $/ \mathrm{ml}$. The most effective/efficient/suitable HPP conditions were used to determine the effect of pressure on microbiological shelf life, particle size and colour of milk during refrigerated storage. Results were compared to pasteurised and raw milk. HPP (600 MPa for $3 \mathrm{~min}$ ) also significantly reduced TVC, Enterobacteriaceae, lactic acid bacteria and Pseudomonas spp. in milk thus prolonging the microbiological shelf life of milk by 1 week compared to pasteurised milk. Particle size distribution curves of raw, pasteurised and HPP milk, showed that raw and HPP milk had more similar casein and fat particle sizes compared to pasteurised milk. The results of this study show the possibility of using HPP to eliminate pathogens present in milk while maintaining key quality characteristics similar to those of raw milk.
\end{abstract}

Commented [1]: Re-write this. Looks like authors do not know/not sure how to phrase it. Not acceptable

Commented [2]: ?

Commented [3]: There is a lot of work done on HPP of milk.
Some references below.
Trujillo, A. J.; Capellas, M.; Saldo, J.;
Gervilla, R. \& Guamis, B. Applications of
high-hydrostatic pressure on milk and dairy
products: a review. Innovative Food Science
and Emerging Technologies 2002, 3(4), 295-
307.
-Datta, N. \& Deeth, H. H. High pressure
processing of milk and dairy products.
Australian Journal of Dairy Technology 1999,
$54(2), 41-48$.
What is the novelty of this work?




\section{INTRODUCTION}

Recently, a strong preference for food products and ingredients that are natural has emerged amongst consumers (Murphy, Martin, Barbano, \& Wiedmann, 2016; Melini, Melini, Luziatelli, \& Ruzzi, 2017). Therefore, the demand for fresh-like food, with high nutrient content and high organoleptic quality has steadily increased (Hong \& Wang, 2015). In this regard, the consumption of raw milk, and dairy products made from raw milk is increasingly considered desirable by some consumers. Raw milk has been identified as the cause of foodborne illness outbreaks in many cases. According to the European Food Safety Authority, 27 illness outbreaks took place within the EU between 2007 and 2012 which were linked with the consumption of raw milk (EFSA 2015). The presence and level of pathogens in milk is determined by different factors, such as season, farm size, farm hygiene and management practices and milking (Griffiths, 2010). Transmission to raw milk can take place either from zoonotic pathogens present within animals or from the environment. Specifically, raw milk can become contaminated with pathogenic bacteria by direct passage from the animal's blood into milk and externally via faecal contamination or contamination from humans. Thus, dairy farms are an important reservoir of various foodborne pathogens (Oliver, Jayarao, \& Almeida, 2005). Pathogenic Escherichia coli, Salmonella spp. and Listeria monocytogenes are amongst the most common pathogenic bacteria found in milk and some of the most commonly reported gastrointestinal bacterial pathogens in humans in the European Union causing milk-borne infections, intoxications and toxicoinfections (Dhanashekar, Akkinepalli, \& Nellutla, 2012; EFSA 2016; Melini et al., 2017). Therefore, pathogens in milk represent a safety risk that needs to be managed. The majority of the countries require raw milk to undergo some level of thermal processing in order to be rendered safe for the consumer (Griffiths 2010; Melini et al., 2017). However, conventional thermal treatment can have a detrimental effect on the nutrient content of milk as well as on
Commented [4]: Provide references (very recent outbreaks.

Commented [5]: Describe the process conditions. 
its organoleptic and physicochemical properties (Buckow, Chandry, Ng, McAuley, \& Swanson, 2014). The recent interest in the consumption of raw milk has led to the consideration of alternative processing technologies for production of milk that is safe but also minimally processed in order to be perceived as fresh by the consumer (Román, Sánchez-Siles, \& Siegrist, 2017). High-pressure processing (HPP) is a food preservation technology and promising alternative to conventional thermal pasteurization as it can inactivate foodborne pathogens while minimising the loss of nutrients, such as vitamins, and maintaining the fresh-like characteristics of food products (Lee \& Kaletunç 2010; Yang et al. 2012; Yao et al. 2014; Sheen, Cassidy, Scullen, \& Sommers, 2015). HPP, although very efficient in eliminating vegetative microorganisms can also influence the physicochemical and technological characteristics of milk by modifying the structure of milk components (Patterson, 2005; Cadesky, Walkling-Ribeiro, Kriner, Karwe, \& Moraru, 2017). Pressurization can result in conformational changes of milk proteins as it can disrupt milk casein micelles as well as the structure of whey proteins (Chawla, Patil, \& Singh, 2011). It does not seem to affect lactose in milk which suggests that no Maillard or lactose isomerization reaction takes place in milk as a result of pressure treatment (Lopez-Fandino, Carrascosa, \& Olano, 1996).

In the current study different levels of HPP were evaluated and compared with thermal pasteurisation and a raw milk control to determine the effect on microbiological safety, microbiological shelf life and quality. Specifically, the objectives were: (i) to identify HPP conditions that can achieve a 5-log reduction in the levels of pathogenic E. coli, Salmonella and L. monocytogenes inoculated in raw milk (ii) to determine the effect of HPP on milk microbiological shelf life and (iii) determine the effect of HPP on milk colour and physicochemical stability.
Commented [6]: Can you comment on the D values of these pathogens>

Commented [7]: Can it work on spores? Are spores resistant to spores? For example Bacillus

Commented [8]: Please break down the paragraphs, Each paragraph needs to have a topic sentence, followed by description of that topic. 
I suggest " The aim of the present study was to demonstrate the inactivation of E. coli, Salmonella and L. monocytogenes in milk using HPP while evaluating any potential impacts on product quality.

\section{MATERIALS AND METHODS}

\subsection{Preparation of $E$. coli, Salmonella and L. monocytogenes inoculum}

5 strain cocktail of the three pathogenic microorganisms was inoculated into raw milk samples separately in three different inoculation studies. The cocktail of $E$. coli consisted of NCTC 11601, NCTC 11602, NCTC 11603, NCTC 9706 and NCTC 9707. The Salmonella cocktail consisted of Salmonella Senftenberg, Salmonella Typhimurium, Salmonella Anatum, Salmonella Agona and Salmonella Saint Paul. The L. monocytogenes cocktail consisted of FMT 1750, NCTC 11994, NCTC 5214, NCTC 10888 and NCTC 19118 strains. These cocktails contained some relatively pressure-resistant strains, a L. monocytogenes strain associated with an outbreak in soft cheese and a L. monocytogenes strain isolated from a dairy processing environment.

For each E. coli, Salmonella and L. monocytogenes strain used, a loopful of a fresh tryptone soya agar (Oxoid code CM0131) $+0.6 \%$ yeast extract (Oxoid code LP0021) (TSAYE) slope culture was inoculated into $10 \mathrm{ml}$ of brain heart infusion broth (BHI) (Oxoid code CM1135) and incubated at $37^{\circ} \mathrm{C}$ for $24 \mathrm{~h}$. Subsequently $100 \mu \mathrm{l}$ of a $10^{-4}$ dilution of this broth was inoculated into another $10 \mathrm{ml} \mathrm{BHI} \mathrm{broth} \mathrm{and} \mathrm{incubated} \mathrm{at} 37^{\circ} \mathrm{C}$ for either $24 \mathrm{~h}$ or $48 \mathrm{~h}$, until the stationary phase of growth was reached. The final $10 \mathrm{ml}$ cultures were centrifuged at $3600 \times \mathrm{g}$, for $30 \mathrm{~min}$, washed twice in phosphate-buffered saline (PBS) and the pellet resuspended in a final volume of $1 \mathrm{ml}$ PBS to give approximately $10^{9}-10^{10} \mathrm{CFU} / \mathrm{ml}$. The suspensions of all 5 strains for each pathogenic microorganism were combined and mixed well. The combined suspensions were inoculated $(100 \mu l)$ into different raw milk samples 
$(10 \mathrm{ml})$, to give a level of approximately $7-8 \log \mathrm{CFU} / \mathrm{ml}$. The $10 \mathrm{ml}$ samples were transferred to polyethylene/polyamide pouches (Somerville Packaging, Lisburn, Northern Ireland) and the pouches heat sealed, excluding as much air as possible. For pressure treatment, the pouches were vacuum packed in a larger pouch and the vacuum pouches were packed in an outer bag containing 5\% Anistel disinfectant. Inoculated samples were held for $24 \mathrm{~h}$ before pressure treatment to allow time for the bacteria to acclimatise to the substrate.

$48 \mathrm{~h}$ after HPP, three samples in total for each of the 3 different treatments and each pathogenic microorganism were opened aseptically and the contents were aseptically transferred to a sterile plastic test-tube. If required, decimal dilutions were prepared in maximum recovery diluent (MRD) (Oxoid code CM733).

\subsection{Raw milk sample preparation and processing}

Milk was supplied by The Village Dairy, Clonmore, Killeshin, Co. Carlow, Ireland. For all analyses conducted raw milk samples were placed either in plastic bottles or in polyethylene/polyamide pouches and heat sealed, excluding as much air as possible. Inoculated packaged raw milk samples were heat pasteurised (controls) in a water bath at 72 ${ }^{\circ} \mathrm{C} \pm 0.5^{\circ} \mathrm{C}$ for $5 \mathrm{~min}$. Pressure treatment of inoculated packaged raw milk samples was performed in a commercial-scale high pressure press (Quintus 35L, Avure Technologies, U.S.A.), with a pressure vessel of $35 \mathrm{~L}$ volume. The pressure transmission fluid used was potable water. The pressure come-up time was approximately $25 \mathrm{~s}$ per $100 \mathrm{MPa}$ and the pressure release time was approximately $10 \mathrm{~s}$. The initial temperature of the water was approximately $18{ }^{\circ} \mathrm{C}$ and the temperature increase due to adiabatic heating was approximately $2-3^{\circ} \mathrm{C}$ per $100 \mathrm{MPa}$. The samples were pressure treated at 400,500 and $600 \mathrm{MPa}$ with a hold time at pressure of 1,3 and 5 min. 
The heat-treated and HPP milk was stored for $48 \mathrm{~h}$ at $4^{\circ} \mathrm{C}$ before enumeration as this gives a better estimate of survivors, as injured cells may either recover or die during subsequent cold storage. Unprocessed inoculated samples were enumerated at the time of pressure processing (i.e. $24 \mathrm{~h}$ after inoculation).

\subsection{Enumeration of E. coli, Salmonella and L. monocytogenes}

For enumeration of pathogenic E. coli an aliquot of $100 \mu 1$ of each of the appropriate 10 -fold dilutions was spread plated on TBX agar plates (Oxoid, CM0945) and the plates incubated at $37^{\circ} \mathrm{C}$ for $24 \mathrm{~h}$. For enumeration of pathogenic Salmonella an aliquot of $100 \mu \mathrm{l}$ of each of the appropriate 10-fold dilutions was spread plated on brilliant green agar plates (Oxoid, $\mathrm{CM} 0329$ ) and incubated at $37^{\circ} \mathrm{C}$ for $24 \mathrm{~h}$. For enumeration of $L$. monocytogenes an aliquot of $100 \mu 1$ of each of the appropriate 10-fold dilutions was spread plated on Palcam agar (Oxoid, code CM0877) supplemented with Palcam selective supplement (Oxoid SR0150) and incubated at $37^{\circ} \mathrm{C}$ for $48 \mathrm{~h}$. Each sample was plated in duplicate.

\subsection{Microbial Shelf-life assessment}

After processing, raw, pasteurised and HPP milk was stored in one litre bottles at $4 \pm 0.5^{\circ} \mathrm{C}$ for the duration of the 28 days shelf life study. Shelf life assessment of samples treated at 600 MPa for 3 min was determined as it was found to be the most promising in terms of pathogen reduction. Ten-fold dilutions of milk samples were prepared in MRD (Oxoid, Basingstoke, Hampshire, U.K.) and serially diluted further. Total mesophilic aerobic bacteria (TVC), were enumerated by spread plating $100 \mu 1$ from each dilution on standard plate count agar (PCA, Oxoid Ltd., Basingstoke, Hampshire, U.K.). Plates were incubated at $30^{\circ} \mathrm{C}$ for $48 \pm 2 \mathrm{~h}$. Numbers of Pseudomonas spp. were determined by spread plating on Pseudomonas agar base with CFC supplement (Oxoid Ltd., Basingstoke, Hampshire, U.K.) incubated for $72 \pm 2 \mathrm{~h}$ at 
$25^{\circ} \mathrm{C}$. Enterobacteriaceae were enumerated by pour plating using violet red bile glucose agar (VRBG, Oxoid Ltd., Basingstoke, Hampshire, U.K.) incubated for $24 \pm 2 \mathrm{~h}$ at $37^{\circ} \mathrm{C}$. Lactic acid bacteria were enumerated on de Man, Rogosa, Sharpe Agar (MRS, Oxoid Ltd., Basingstoke, Hampshire, U.K.), incubated for $48 \pm 2 \mathrm{~h}$ at $30{ }^{\circ} \mathrm{C}$. Results were reported as $\log _{10}$ CFU ml ${ }^{-1}$. Samples were taken on days $0,5,7,14,21$ and 28 for microbiological, particle size and color analysis. Day 0 was set as the first day after high pressure treatment.

\subsection{Particle size analysis}

Particle size analysis was carried out on day 0 and after 7 days of storage for raw, pasteurised and HPP treated milk (600 MPa for 3 min) using a Malvern Mastersizer 3000 laser diffraction particle size analyser (Malvern Instruments, GB). The sample was added in drops (approximately 4-5 drops) into the dispersant (distilled water). Refractive Index ( $n r)$ of the sample was 1.33 for the dispersant, 1.38 and 1.45 for casein and fat particle sizes respectively. The particle diameters were expressed as: $\mathrm{D}[(3,2)]$, the area mean weighted average surface diameter, which measured spherical particles of the same surface area (Sauter mean diameter, according to eq. 1$) ; \mathrm{D}[(4,3)]$, the volume moment mean weighted average volume diameter, which measure the spherical particles having the same volume (De Brouckere mean diameter, according to eq. 2$)$; $d(0.9)$, indicates that $90 \%$ of the volume distribution is below observed diameter and $\mathrm{d}(0,5)$ or median diameter, which indicates that $50 \%$ of the volume distribution is above, and $50 \%$ is below the observed diameter.

$$
\begin{aligned}
& \mathrm{D}(3,2)=\frac{\sum_{i} n(i) X d(i)^{3}}{\sum_{i} n(i) X d(i)^{2}} \\
& \mathrm{D}(4,2)=\frac{\sum_{i} n(i) X d(i)^{4}}{\sum_{i} n(i) X d(i)^{3}}
\end{aligned}
$$

where $(n)$ is the number of fat and casein globules having a diameter [m] identical to $d(i)$. Particles size measurements were performed in triplicates at Day 0 and Day 7 for raw, thermally and HPP milk. 


\subsection{Color Measurement}

Instrumental colour analysis was performed at day $0,5,7,14,21$ and 28 of storage at $4^{\circ} \mathrm{C}$ for all the samples. Before each measurement samples were mixed by shaking and $200 \mathrm{ml}$ of milk poured into a $50 \mathrm{~mm}$ glass bottle so that it was filled to the top. Colour readings were taken in triplicate by emptying and refilling the bottle at each measurement. Measurements were performed using a dual beam spectrometer Hunter Lab system (UltraScan XE, Hunter Lab., VA, USA). Measurements were reported as distribution of CIE L* (lightness), a* (redness) and $b^{*}$ (yellowness) and the value used to calculate the total color difference between the samples $\left(\Delta \mathrm{E}=\operatorname{sqrt}(\Delta \mathrm{L})^{2}+(\Delta \mathrm{a})^{2}+(\Delta \mathrm{b})^{2}\right)$. Depending on the value of $\Delta \mathrm{E}$ the color difference between treated and untreated samples could be estimated such as not noticeable $(0-0.5)$, slightly noticeable $(0.5-1.5)$, noticeable $(1.5-3.0)$, well visible $(3.0-6.0)$ and great (6.0-12.0) according to Cserhalmi, Sass-Kiss, Tóth-Markus, and Lechner (2006).

\subsection{Statistical analysis}

The entire experiment was replicated on three different occasions. Data were subjected to a analysis of variance (ANOVA) with treatment and storage time as the main effects and their interaction. Differences between groups were assessed by the Tukey's test. A significance level of 0.05 was used.

\section{RESULTS AND DISCUSSION}

\subsection{Initial considerations on experimental design}

This study focused on the pathogens E. coli, Salmonella and L. monocytogenes because they have been linked to many outbreaks in raw milk and thus of concern for the food industry (Rodriguez, Arques, Nunez, Gaya, \& Medina 2005; Oliver et al. 2005; Tambekar, \& Bhutda,
Commented [15]: Does the authors plan to do sensory analysis of HPP milk? This would be a very useful piece of information for

the industry.

Commented [16]: Randomized? 
2010). Literature has shown that bacterial cells in the stationary phase of growth exhibit greater pressure tolerance than exponentially-growing cells (Hayman, Anantheswaran, \& Knabel, 2007; McClements, Patterson, \& Linton, 2001). Therefore, bacteria were inoculated at the stationary phase in order to assess the efficiency of pressure to simulate the worst case scenario. In some cases, HPP can result in sub-lethally injured cells which cannot be detected on selective media. These cells can potentially repair themselves and cause disease. Repair of foodborne pathogens during storage is important for HPP low-acid foods such as milk because it can cause overestimation of safety (Jordan, Pascual, Bracey, \& Mackey, 2001; Russell, 2002). It has also been shown that in some cases sub-lethally injured pathogens such as E. coli can recover even in a nutrient-free environment (Koseki \& Yamamoto, 2006). To tackle that in the present study the pressure-treated milk was held for $48 \mathrm{~h}$ at $4^{\circ} \mathrm{C}$ to allow time for sub-lethally injured cells to either recover or die off. These samples were then enumerated. Here, raw milk was inoculated with individual cocktails of the three pathogenic bacteria at a high level in order to determine which pressure conditions are able to give a 5$\log$ reduction in CFU. Specifically, E.coli, Salmonella and L. monocytogenes were inoculated at $8.11,8.33$ and $7.19 \log \mathrm{CFU} / \mathrm{ml}$ of milk, respectively. Pasteurisation resulted in a reduction of E. coli, Salmonella and $L$. monocytogenes below the detection limit, which corresponds to a $>7.11,>7.33$ and $>6.19 \log \mathrm{CFU} / \mathrm{ml}$ reduction, respectively.

\subsection{Influence of HPP on the inactivation of E. coli, Salmonella and L. monocytogenes.}

The effect of increasing pressure (400-600 MPa) and exposure time (1-3 min) from 400 to $600 \mathrm{MPa}$ on the survival of the three artificially inoculated pathogens in raw milk is presented in Fig. 1. In general, for all three microorganisms a more pronounced inactivation was obtained with increasing pressure levels and increasing exposure time $(\mathrm{P}<0.05)$. In all cases, HPP application even at the lower pressure level (400 MPa) and exposure time (1 min) resulted in a significant reduction $(\mathrm{P}<0.05)$ in the levels of E. coli, Salmonella spp. and $L$.
Commented [17]: This should be removed, move it to introduction.

Commented [18]: These statements are too wordy, re-phrase.

Commented [19]: This should be moved to methods.....

Commented [20]: What is $D$ value of these pathogens in buffer? This data is very important and should be included in this paragraph. Microbe sensitivity to pressure is very important, the treatments can then be fine-tuned to get $99.999 \%$ reduction. 
monocytogenes $(0.85,1.09$ and $1.42 \mathrm{log}$ reduction, respectively) compared to the control (raw milk). With regards to pathogenic E. coli, although HPP at $400 \mathrm{MPa}$ and $500 \mathrm{MPa}$ for $1 \mathrm{~min}$ did not result in statistically significant differences in reduction levels, at longer exposure times ( 3 and $5 \mathrm{~min}$ ) there was a significantly higher reduction between the 400 and $500 \mathrm{MPa}$ treatments. Application of pressure at $600 \mathrm{MPa}$ for 3 and 5 min resulted in a reduction of 5.6 and $6.8 \log$ CFU/ml, respectively. Linton, McClements and Patterson (2001) observed that pressure inactivation of pathogenic E. coli in skimmed milk varied between 3.4 and 6.7 log using a pressure treatment of $600 \mathrm{MPa}$ for $15 \mathrm{~min}$. Ramaswamy, Jin, \& Zhu, (2009) demonstrated that HPP at $200 \mathrm{MPa}$ for $15 \mathrm{~min}$ or $300 \mathrm{MPa}$ for 5 min resulted in similar reduction of E. coli K12 counts (approx. $1.2 \operatorname{logs}$ ) in milk. In general, Salmonella exhibited the same trend as pathogenic E. coli (Fig. 1B). Reduction for $400 \mathrm{MPa}$ for 1-5 min ranged from 1.09 to $2.36 \log \mathrm{CFU} / \mathrm{ml}$ and for $500 \mathrm{MPa}$ for $1-5$ min ranged from 1.17 to $3.28 \log$ $\mathrm{CFU} / \mathrm{ml}$. Significantly higher reductions were achieved at $600 \mathrm{MPa}$ compared to the lower pressure levels $(\mathrm{P}<0.05)$. Specifically, $\mathrm{HPP}$ at $600 \mathrm{MPa}$ for 1,3 and 5 min resulted in 2.48, 5.06 and $6.27 \log$ CFU reduction in Salmonella counts, respectively. Similar results were obtained by Guan, Chen, \& Hoover (2005) when pressure treated UHT whole milk. They found that $S$. typhimurium was reduced by $0.6,1.8$, and $5.0 \log _{10} \mathrm{CFU} / \mathrm{ml}$, at pressures of 350 , 400 , and $450 \mathrm{MPa}$ for $30 \mathrm{~min}$, respectively. Whereas pressures of 500, 550, and $600 \mathrm{MPa}$ for 10 min reduced counts of $S$. typhimurium by approx. $4.5-5.1$ logs. L. monocytogenes survival after HPP is presented in Fig. 1C. In this case as well increasing pressure and exposure time resulted in more pronounced pathogen reduction. The milder conditions that could achieve a $>5 \log$ reduction in the pathogen levels were $500 \mathrm{MPa}$ for $5 \mathrm{~min}(5.48 \operatorname{logs})$ and $600 \mathrm{MPa}$ for $3 \mathrm{~min}(5.65 \operatorname{logs})$. Pressure applied at $600 \mathrm{MPa}$ for 5 min resulted in 5.91 $\log \mathrm{CFU} / \mathrm{ml}$ which did not differ significantly to the $600 \mathrm{MPa}$ for 3 min treatment $(\mathrm{P}>0.05)$ The most pronounced reduction was observed when $600 \mathrm{MPa}$ were applied to the raw milk 
However, there were no statistically differences between the L. monocytogenes counts at 600 $\mathrm{MPa}$ for $3 \mathrm{~min}$ and $600 \mathrm{MPa}$ for $5 \mathrm{~min}(\mathrm{P}>0.05)$. This suggests that L. monocytogenes was more sensitive to increasing pressure than increasing exposure time (Erkmen \& Dogan 2004), at least in the higher pressure levels. Koseki, Mizuno, \& Yamamoto, (2008) found that $L$. monocytogenes cells artificially inoculated in milk $\left(7 \log _{10} \mathrm{CFU} / \mathrm{ml}\right)$ can be reduced after $\mathrm{HPP}$ at $500 \mathrm{MPa}$ for $5 \mathrm{~min}$ by $5 \log \mathrm{CFU} / \mathrm{ml}$. Whereas, HPP above 550 and $600 \mathrm{MPa}$ reduced the number of $L$. monocytogenes cells to below the limit of detection $(<1 \mathrm{CFU} / \mathrm{ml})$ immediately after treatment. According to Erkmen \& Dogan, (2004), HPP at 400 and 600 MPa for 10 min resulted in 2.76 and $6.47 \log \mathrm{CFU} / \mathrm{ml}$ reduction in L. monocytogenes counts in raw milk. Misiou, van Nassau, Lenz, \& Vogel (2017) inoculated L. monocytogenes in milk at similar inoculum level $(7.4 \log \mathrm{CFU} / \mathrm{ml})$ as in the present study and found that 300 MPa for $10 \mathrm{~min}$ did not have any effect on the pathogen counts. When pressures of 400 and $500 \mathrm{MPa}$ were applied reductions of approx. 4.7 and 6.2 logs were observed, respectively. Based on these results, the lowest HPP condition set that were capable of reducing the levels of all three pathogenic bacteria by $>5 \log$ was the $600 \mathrm{MPa}$ for $3 \mathrm{~min}$ set. These conditions were therefore assessed in subsequent experiments.

\subsection{Effect of HPP on microbiological shelf life}

As soon as the raw milk is obtained from the animal it can be contaminated by a complex spoilage bacterial microbiota which can be present on the animal itself and/or the environment. These microorganisms can affect the nutritional and organoleptic characteristics of milk (Melini et al. 2017). The TVC, Enterobacteriaceae, lactic acid bacteria (LAB) and Pseudomonas spp. counts of raw milk were determined immediately after treatment and during refrigerated storage (Fig. 2). The TVC counts for the raw milk were approx. 6 log $\mathrm{CFU} / \mathrm{ml}$ at the beginning of storage. Pasteurisation led to a significant reduction of $1.19 \mathrm{log}$ 
$\mathrm{CFU} / \mathrm{ml}$ whereas HPP (600 MPa at $3 \mathrm{~min}$ ) led to a more pronounced decrease of $3.95 \mathrm{log}$ $\mathrm{CFU} / \mathrm{ml}$, immediately after treatment. After 5 days storage, the TVC of the pasteurised milk, did not differ significantly compared to the raw milk $(\mathrm{P}>0.05)$ for the remaining storage period. The TVC for HPP milk was always lower compared to the other two treatments with the TVC in HPP milk reaching $7.05 \log$ CFU/ml after 28 days compared with 14 days to reach $>7 \log$ for raw and pasteurised milk. Pasteurisation also resulted in a significant reduction in Enterobacteriaceae counts by approx. $1.7 \log \mathrm{CFU} / \mathrm{ml}$ compared to the raw milk and reached $7.87 \log \mathrm{CFU} / \mathrm{ml}$ after 21 days. Whereas HPP was able to reduce the levels to below the detection limit, and the counts remained at this level throughout storage. LAB levels in raw milk were $4.26 \log \mathrm{CFU} / \mathrm{ml}$ at the beginning of storage and reached $7.93 \mathrm{log}$ $\mathrm{CFU} / \mathrm{ml}$ after 14 days. Pasteurisation reduced the LAB counts by $2.2 \log \mathrm{CFU} / \mathrm{ml}$ and increased during storage reaching $7.92 \log \mathrm{CFU} / \mathrm{ml}$ after 21 days. On the other hand, HPP reduced the $\mathrm{LAB}$ levels below the detection limit and were detected again at 14 days storage, reaching $7.17 \log \mathrm{CFU} / \mathrm{ml}$ after 28 days, which was significantly lower $(\mathrm{P}<0.05)$ compared to LAB levels of the pasteurised milk at day 21. Pseudomonas spp. in the untreated raw milk increased during storage and reached $8.16 \log \mathrm{CFU} / \mathrm{ml}$ after 14 days. Pasteurisation reduced Pseudomonas spp. by $1.28 \log \mathrm{CFU} / \mathrm{ml}$ immediately after treatment. Its levels increased during storage and after 21 days it reached $7.45 \log \mathrm{CFU} / \mathrm{ml}$. On the other hand, HPP reduced the Pseudomonas spp. to below the detection limit, where it remained for at least 7 days. After 21 days, Pseudomonas spp. levels were $5.63 \log \mathrm{CFU} / \mathrm{ml}$, which was significantly lower compared to the pasteurised milk. At 28 days, Pseudomonas spp. counts reached 6.91 $\log \mathrm{CFU} / \mathrm{ml}$ for the HPP treatment. Results clearly showed that HPP (600 MPa for $3 \mathrm{~min}$ ) was able to significantly reduce TVC, Enterobacteriaceae, LAB, and Pseudomonas spp. and prolong the microbiological shelf life of milk by 7 days compared to pasteurised milk. Erkmen \& Dogan (2004) found that HPP at 400 and $600 \mathrm{MPa}$ for 10 min could reduce the 
aerobic bacteria counts in raw milk by 2.09 and $5.09 \log \mathrm{CFU} / \mathrm{ml}$, respectively. High pressure homogenisation has also been applied to raw milk to increase its shelf life and has been found to reduce psychrotrophs, lactococci, and total bacteria count by approx. $4 \log \mathrm{CFU} / \mathrm{ml}$ in raw milk. When the high pressure homogenised milk was stored at $4^{\circ} \mathrm{C}$, the microbiological shelf life was 14-18 days, similar to that of pasteurised milk $\left(90^{\circ} \mathrm{C}\right.$ for $\left.15 \mathrm{~s}\right)$ (Pereda, Ferragut, Quevedo, Guamis, \& Trujillo, 2007).

\subsection{Effect of HPP on casein particles}

It is well know that HPP can affect milk constituents such as proteins and fat whereas compounds such as vitamins, amino acids, simple sugars and flavour compounds tend to remain unaffected (Chawla et al., 2011). The effects of HPP on the particle sizes of milk are particularly important since they influence its microstructure and define many properties such as colloidal stability, texture, colour etc. Differences in milk particle size can significantly affect milk quality and its further processing.

Average volume diameter $\mathrm{D}[(4,3)]$ and average surface diameter $\mathrm{D}[(3,2)]$ for all the three treatments tested, along with the percentile values of distribution $d(0.5)$ and $d(0.9)$ are presented in Table 1. For casein particle sizes, HPP treatment significantly $(\mathrm{P}<0.05)$ increased all size parameters at day 0 and day 7, compared to thermally treated milk, showing similarities in $\mathrm{D}[(4,3)]$ and $\mathrm{D}[(3,2)]$ to those observed for raw milk. From the particle size distribution curve of raw, thermal and HPP treated milk, it can be seen that raw and HPP milk had similar peaks at $2.2 \mu \mathrm{m}$ ? and $\sim 2 \mu \mathrm{m}$, while pasteurised milk has a major peak at $\sim 0.5 \mu \mathrm{m}$ corresponding to the smaller casein micelles (Fig. 3). A similar pattern was observed after 7 days of storage for raw and HPP milk showing the same peaks at $1.88 \mu \mathrm{m}$, while the peak for pasteurised milk appeared was at $0.46 \mu \mathrm{m}$, suggesting that the effect of HPP on casein sizes are irreversible during storage time. It has been previously reported that 
when HPP is applied the size and number of casein micelles tend to increase due to the dissociation of casein micelle into sub-micelles (Huppertz, Fox, de Kruif, \& Kelly, 2006). However, diverse effects on milk proteins have been reported based on different pressures and holding times; for example, the average size of casein micelles of milk treated at 100 $200 \mathrm{MPa}$ at ambient temperature was comparable to untreated milk, while a pressure of 250 $\mathrm{MPa}$, yielded considerably larger casein micelles than untreated milk (Huppertz, Fox, \& Kelly, 2004; Regnault, Thiebaud, Dumay, \& Cheftel, 2004). Decreases in micelle diameter were observed after treatment of raw or pasteurized skim milk at 400 and $600 \mathrm{MPa}$, with treated samples having $\sim 50 \%$ smaller casein micelles than those in untreated milk (Needs, et al., 2000; Needs, Stenning, Gill, Ferragut, \& Rich, 2000; Regnault et al., 2004). However, increases in average casein micelle size were observed after treatment at $200 \mathrm{MPa}$ for $60 \mathrm{~min}$ at 30 or $40{ }^{\circ} \mathrm{C}$ or after treatment at $300 \mathrm{MPa}$ for $5 \mathrm{~min}$ at $40{ }^{\circ} \mathrm{C}$ (Anema, Lowe, \& Stockmann, 2005). Cadesky et al. (2017) reported similar changes in particle sizes as a result of pressure treatment at pressures greater than $250 \mathrm{MPa}$; increasing the pressure in low milk proteins concentration $(2.5 \%)$ resulted in progressively smaller particle sizes, while for higher protein concentration $(10 \%)$ a significant increase in particle size was observed. Increase in the average micelle size induced by HPP is most likely due to the presence of large casein aggregates in the milk; the results of the present study seem to support this view and are consistent with other studies where the presence of large casein aggregates in HPP treated milk was determined by electron microscopy (Considine, Patel, Anema, Singh, \& Creamer, 2007; Garcia-Risco, Olano, Ramos, \& Lopez-Fandino, 2000; Gaucheron et al., 1997; Needs et al. 2000).

\subsection{Effect of HPP on fat particles}


The particle size of the fat droplets present in dairy products is important in defining properties such as flavor release, mouth feel and the emulsion stability. Along with changes in milk proteins, HPP has been also linked with modifications of fat globules. In particular, the use of HPP has been observed to contribute to homogenization of dairy products due to a reduction of fat globule size; smaller globules cannot form large enough clusters for creaming to occur, resulting in an increased shelf-life for the milk. According to the literature, typical parameters for the size distributions of particles for homogenized milk at pressure of 100 MPa for D $[(4,3)]$ and a D $[(3,2)]$ are of about $0.5 \mu \mathrm{m}$ and $0.2 \mu \mathrm{m}$. For non-homogenized milk, respective values of $4.5 \mu \mathrm{m}$ and $1 \mu \mathrm{m}$ are usually observed (Tobin, Heffernan, Mulvihill, Huppertz, \& Kelly, 2015). Table 2 shows the fat particle size distribution of raw, pasteurised and HPP milk samples after 0 and 7 days of storage at $4^{\circ} \mathrm{C}$. In the present study, HPP of milk at $600 \mathrm{MPa}$ for $3 \mathrm{~min}$ did not result in a significant reduction of the fat particle size. Pasteurised milk displayed significant smaller $(\mathrm{P}<0.05)$ average size distribution for fat globules compared to raw and HPP milk, (Fig. 3). Studies have shown that minimum fat particle sizes are observed after pressure application at 200-250 MPa (Picart et al., 2006; Serra, Trujillo, Quevedo, Guamis, \& Ferragut, 2007), while above $250 \mathrm{MPa}$ the size of the fat globules may actually increase. This has been attributed to the formation of a too large surface area which would cause the formation of cluster between the fat globules (Pereda et al., 2007; Serra et al., 2007).

\subsection{Colour evaluation}

The white colour of milk is due to scattering of light particles by fat globules and casein micelles and generally, the Hunter Luminance value ( $\mathrm{L}^{*}$ value) is used as a measure of the whiteness of a liquid (Harte, Luedecke, Swanson, \& Barbosa-Cánovas, 2003). As discussed previously, different treatments can cause changes in the size of fat particles and micelle 
disintegration, resulting in different light scatter and therefore differences in colour. Results of the colour parameters distribution during the storage time of milk samples are shown in Table 3. Pasteurised milk presented the highest $L^{*}$ values; significant changes $(\mathrm{P}<0.05)$ could be detected after HPP with $L^{*}$ value closer to raw milk $L^{*}$ values. This is in agreement with Chawla et al. (2011) and Tao, Sun, Hogan, and Kelly (2014). A similar trend was found by Naik, Sharma, \& G. (2013) in skimmed milk after treatment at 250-450 MPa, where a significant decrease in the $L^{*}$ values was observed, and in ewe`s milk, by Gervilla, Ferragut, \& Guamis (2001). Also, Harte et al. (2003) reported that milk subjected to HPP or thermal treatment followed by high pressure, loses its white colour and turns yellowish. Significant differences $(\mathrm{P}<0.05)$ were observed in the colour parameter $-a^{*}$ (greenness) of raw milk $(-$ $0.34 \pm 0.05)$ compared to HPP $(-0.61 \pm 0.08)$ and thermal treated $(-0.72 \pm 0.06)$ milk. For the $+b^{*}$ value (yellowness), HPP caused a significant $(14.03 \pm 0.30)$ increase $(\mathrm{P}<0.05)$ compared to raw milk $(12.49 \pm 0.26)$ and to pasteurised milk samples $(9.79 \pm 0.19)$. The total colour difference $(\Delta \mathrm{E})$ parameter is used to indicate the degree of colour difference between treated/untreated samples or before/after storage (Barba, Esteve, \& Frígola, 2012) and values can be classified as not noticeable $(0-0.5)$, slightly noticeable $(0.5-1.5)$, noticeable (1.5-3.0), well visible (3.0-6.0) and great (6.0-12.0) (Cserhalmi et al., 2006).. According to this, noticeable colour differences could be observed at the beginning of the shelf life between HPP and raw milk ( $\Delta \mathrm{E} 2.82)$ and between raw and thermally-treated milk ( $\Delta \mathrm{E} 2.95)$, while well visible differences could be seen between HPP and thermally-treated milk ( $\Delta \mathrm{E} 5.69)$. Moving towards the end of shelf life (based on LAB bacterial count), the perceived colour difference between HPP and raw milk decreased to slightly noticeable ( $\Delta \mathrm{E} 1.41)$ while remained in the range of well visible for HPP compared to thermally treated milk ( $\Delta \mathrm{E} 4.98)$ and raw to thermal milk samples $(\Delta \mathrm{E} 3.65)$. These observations are in line with previous studies where optical parameters were reported not to be affected after treatment of milk at 
100-200 MPa, but were reduced progressively with treatment pressures of 200-400 MPa, with further reduction when pressures $>400 \mathrm{MPa}$ was applied. Moreover, changes in optical parameters became irreversible during subsequent storage at $5{ }^{\circ} \mathrm{C}$ (Huppertz et al. 2004; Huppertz et al., 2006).

\section{CONCLUSION}

This study demonstrated that HPP was effective in achieving 5 log reductions for pathogenic E. coli, Salmonella and L. monocytogenes respectively. It is envisaged that HPP prolonged the shelf life of raw milk by reducing TVC, Enterobacteriaceae, LAB and Pseudomonas spp. levels compared to pasteurised and raw milk.. The particle size and color analysis of HPP milk compared to raw and pasteurized milk, revealed that HPP milk seem to preserve the quality attributes which characterize raw unprocessed milk, such as color and mouth feel sensation due to particle size. Since the demand for unpasteurized raw milk appears to be growing, HPP could be a viable alternative for the dairy industry in order to produce microbiologically safe milk with fresh-like characteristics.

Acknowledgements: The authors would like to thank Joan Tollerton (AFBI) for facilitating the research conducted with the High Pressure Processing equipment. 


\section{REFERENCES}

Anema, S. G., Lowe, E. K., \& Stockmann, R. (2005). Particle size changes and casein solubilisation in high-pressure-treated skim milk. Food Hydrocolloids, 19, 257-267.

Barba, F. J., Esteve, M. J., \& Frígola, A. (2012). High Pressure Treatment Effect on Physicochemical and Nutritional Properties of Fluid Foods During Storage: A Review. Comprehensive Reviews in Food Science and Food Safety, 11, 307-322.

Buckow, R., Chandry, P. S., Ng, S. Y., McAuley, C. M., \& Swanson, B. G. (2014). Opportunities and challenges in pulsed electric field processing of dairy products. International Dairy Journal, 34, 199-212.

Cadesky, L., Walkling-Ribeiro, M., Kriner, K. T., Karwe, M. V., \& Moraru, C. I., (2017). Structural changes induced by high-pressure processing in micellar casein and milk protein concentrates. Journal of Dairy Science, 100, 7055-7070.

Chawla, R., Patil, G. R., \& Singh, A. K., (2011). High hydrostatic pressure technology in dairy processing: a review. Journal of Food Science and Technology, 48, 260-268.

Considine, T., Patel, H. A., Anema, S. G., Singh, H., \& Creamer, L. K. (2007). Interactions of milk proteins during heat and high hydrostatic pressure treatments - A Review. Innovative Food Science \& Emerging Technologies, 8, 1-23.

Cserhalmi, Z., Sass-Kiss, Á., Tóth-Markus, M., \& Lechner, N. (2006). Study of pulsed electric field treated citrus juices. Innovative Food Science \& Emerging Technologies, 7, 49-54.

Dhanashekar, R., Akkinepalli, S., \& Nellutla, A., (2012). Milk-borne infections. An analysis of their potential effect on the milk industry. Germs, 2, 101.

EFSA (European Food Safety Authority), (2016). The European Union summary report on trends and sources of zoonoses, zoonotic agents and food-borne outbreaks in 2015 . EFSA Journal, 14, 4634. 
EFSA Panel on Biological Hazards (BIOHAZ). Scientific Opinion on the Public Health Risks Related to the Consumption of Raw Drinking Milk: Public Health Risks Related to Raw Drinking Milk. EFSA Journal, 13, 3940.

Erkmen, O., \& Dogan, C., (2004). Effects of ultra high hydrostatic pressure on Listeria monocytogenes and natural flora in broth, milk and fruit juices. International Journal of Food Science \& Technology, 39, 91-97.

Garcia-Risco, M. R., Olano, A., Ramos, M., \& Lopez-Fandino, R. (2000). Micellar changes induced by high pressure. influence in the proteolytic activity and organoleptic properties of milk. Journal of Dairy Science, 83, 2184-2189.

Gaucheron, F., Famelart, M. H., Mariette, F., Raulot, K., Michela, F., \& Le Graeta, Y. (1997). Combined effects of temperature and high-pressure treatments on physicochemical characteristics of skim milk. Food Chemistry, 59, 439-447.

Gervilla, R., Ferragut, V., \& Guamis, B. (2001). High Hydrostatic Pressure Effects on Color and Milk-Fat Globule of Ewe's Milk. Journal of Food Science, 66, 880-885.

Griffiths, M. W. (2010). The microbiological safety of raw milk. In: Griffiths MW, (Ed.), Improving the Safety and Quality of Milk, Volume 1: Milk Production and Processing. (27-63). Boca Raton, FL: CRC Press.

Guan, D., Chen, H., \& Hoover, D. G. (2005). Inactivation of Salmonella typhimurium DT 104 in UHT whole milk by high hydrostatic pressure. International Journal of Food Microbiology, 104, 145-153.

Harte, F., Luedecke, L., Swanson, B., \& Barbosa-Cánovas, G. V. (2003). Low-fat set yogurt made from milk subjected to combinations of high hydrostatic pressure and thermal processing. Journal of Dairy Science, 86, 1074-1082.

Hayman, M. M., Anantheswaran, R. C., \& Knabel, S. J., (2007). The effects of growth temperature and growth phase on the inactivation of Listeria monocytogenes in whole 
milk subject to high pressure processing. International Journal of Food Microbiology, 115, 220-226.

Hong, X., \& Wang, J., (2015). Use of electronic nose and tongue to track freshness of cherry tomatoes squeezed for juice consumption: comparison of different sensor fusion approaches. Food and Bioprocess Technology, 8, 158-170.

Huppertz, T., Fox, P. F., \& Kelly, A. L. (2004). Properties of casein micelles in high pressure-treated bovine milk. Food Chemistry, 87, 103-110.

Huppertz, T., Fox, P. F., de Kruif, K. G., \& Kelly, A. L. (2006). High pressure-induced changes in bovine milk proteins: a review. Biochim Biophys Acta, 1764, 593-598.

Jordan, S. L., Pascual, C., Bracey, E., \& Mackey, B. M. (2001). Inactivation and injury of pressure-resistant strains of Escherichia coli $\mathrm{O} 157$ and Listeria monocytogenes in fruit juices. Journal of Applied Microbiology, 91, 463-469.

Koseki, S., \& Yamamoto, K., (2006). Recovery of Escherichia coli ATCC 25922 in phosphate buffered saline after treatment with high hydrostatic pressure. International Journal of Food Microbiology, 110, 108-111.

Koseki, S., Mizuno, Y. \& Yamamoto, K. (2008). Use of mild-heat treatment following highpressure processing to prevent recovery of pressure-injured Listeria monocytogenes in milk. Food Microbiology, 25, 288-293.

Kumar, R., \& Prasad, A., (2010). Detection of E. coli and Staphylococcus in milk and milk products in and around Pantnagar. Pakistan Journal of Nutrition, 1, 151-52.

Lee, J., \& Kaletunç, G. (2010). Inactivation of Salmonella Enteritidis strains by combination of high hydrostatic pressure and nisin. International Journal of Food Microbiology, 140, 49-56. 
Lopez-Fandino, R., Carrascosa, A. V., \& Olano, A., (1996). The effects of high pressure on whey protein denaturation and cheese-making properties of raw milk. Journal of Dairy Science, 79, 929-936.

Lucey, J. A. (2015). Raw Milk Consumption: Risks and Benefits. Nutrition Today, 50, 189193.

McClements, J. M. J., Patterson, M. F., \& Linton, M., (2001). The effect of growth stage and growth temperature on high hydrostatic pressure inactivation of some psychrotrophic bacteria in milk. Journal of Food Protection, 64, 514-522.

Melini, F., Melini, V., Luziatelli, F., \& Ruzzi, M., (2017). Raw and Heat-Treated Milk: From Public Health Risks to Nutritional Quality. Beverages, 3, 54.

Misiou, O., van Nassau, T. J., Lenz, C. A., \& Vogel, R. F., (2017). The preservation of Listeria-critical foods by a combination of endolysin and high hydrostatic pressure. International Journal of Food Microbiology, 266, 355-362.

Murphy, S. C., Martin, N. H., Barbano, D. M., \& Wiedmann, M., (2016). Influence of raw milk quality on processed dairy products: How do raw milk quality test results relate to product quality and yield? Journal of Dairy Science, 99, 10128-10149.

Linton, M., McClements, J. M. J. \& Patterson, M. F., (2001). Inactivation of pathogenic Escherichia coli in skimmed milk using high hydrostatic pressure. Innovative Food Science \& Emerging Technologies, 2, 99-104.

Naik L., Sharma R., S., R. Y., \& G., M. (2013). Application of High Pressure Processing Technology for Dairy Food Preservation - Future Perspective: A Review. Journal of Animal and Veterinary Advances, 3, 232-241.

Needs, E. C., Capellas, M., Bland, A. P., Manoj, P., Macdougal, D., \& Paul, G. (2000). Comparison of heat and pressure treatments of skim milk, fortified with whey protein 
concentrate, for set yogurt preparation: effects on milk proteins and gel structure. Journal of Dairy Research, 67, 329-348.

Needs, E. C., Stenning, R. A., Gill, A. L., Ferragut, V., \& Rich, G. T. (2000). High-pressure treatment of milk: effects on casein micelle structure and on enzymic coagulation. Journal of Dairy Research, 67, 31-42.

Oliver, S. P., Jayarao, B. M., \& Almeida, R. A. (2005). Foodborne pathogens in milk and the dairy farm environment: food safety and public health implications. Foodborne Pathogen and Disease, 2, 115-129.

Olson, D. W., White, C. H., \& Richter, R. L. (2004). Effect of Pressure and Fat Content on Particle Sizes in Microfluidized Milk. Journal of Dairy Science, 87, 3217-3223.

Patterson, M. F., (2005). Microbiology of pressure-treated foods. Journal of Applied Microbiology, 98, 1400-1409.

Pereda, J., Ferragut, V., Quevedo, J. M., Guamis, B., \& Trujillo, A. J. (2007). Effects of Ultra-High Pressure Homogenization on Microbial and Physicochemical Shelf Life of Milk. Journal of Dairy Science, 90, 1081-1093.

Pereda, J., Ferragut, V., Quevedo, J.M., Guamis, B., \& Trujillo, A. J., 2007. Effects of ultrahigh pressure homogenization on microbial and physicochemical shelf life of milk. Journal of Dairy Science, 90, 1081-1093.

Picart, L., Thiebaud, M., René, M., Pierre Guiraud, J., Cheftel, J. C., \& Dumay, E. (2006). Effects of high pressure homogenisation of raw bovine milk on alkaline phosphatase and microbial inactivation. A comparison with continuous short-time thermal treatments. Journal of Dairy Research, 73, 454-463.

Ramaswamy, H. S., Jin, H., \& Zhu, S. (2009). Effects of fat, casein and lactose on highpressure destruction of Escherichia coli K12 (ATCC-29055) in milk. Food and Bioproducts Processing, 87, 1-6. 
Regnault, S., Thiebaud, M., Dumay, E., \& Cheftel, J. C. (2004). Pressurisation of raw skim milk and of a dispersion of phosphocaseinate at $9^{\circ} \mathrm{C}$ or $20^{\circ} \mathrm{C}$ : effects on casein micelle size distribution. International Dairy Journal, 14, 55-68.

Rodriguez, E., Arques, J. L., Nunez, M., Gaya, P., \& Medina, M. (2005). Combined effect of high-pressure treatments and bacteriocin-producing lactic acid bacteria on inactivation of Escherichia coli $\mathrm{O} 157: \mathrm{H} 7$ in raw-milk cheese. Applied and Environmental Microbiology, 71, 3399-3404.

Román, S., Sánchez-Siles, L. M., \& Siegrist, M. (2017). The importance of food naturalness for consumers: Results of a systematic review. Trends in Food Science and Technology, 67, 44-57.

Russell, N. J., (2002). Bacterial membranes: the effects of chill storage and food processing. An overview. International Journal of Food Microbiology, 79, 27-34.

Serra, M., Trujillo, A. J., Quevedo, J. M., Guamis, B., \& Ferragut, V. (2007). Acid coagulation properties and suitability for yogurt production of cows' milk treated by high-pressure homogenisation. International Dairy Journal, 17, 782-790.

Sheen, S., Cassidy, J., Scullen, B., \& Sommers, C. (2015). Inactivation of a diverse set of shiga toxin-producing Escherichia coli in ground beef by high pressure processing. Food Microbiology, 52, 84-87.

Tambekar, D. H., \& Bhutda, S. A., (2010). Prevalence of Bacterial Pathogens in Pedha (A Milk Product) Sold in Amravati (India). International Journal of Dairy Science, 5, 173176.

Tao, Y., Sun, D.-W., Hogan, E., \& Kelly, A. L. (2014). Chapter 1 - High-Pressure Processing of Foods: An Overview. In D.-W. Sun (Ed.), Emerging Technologies for Food Processing (Second Edition) (pp. 3-24). San Diego: Academic Press. 
Tobin, J., Heffernan, S. P., Mulvihill, D. M., Huppertz, T., \& Kelly, A. L. (2015). Applications of High-Pressure Homogenization and Microfluidization for Milk and Dairy Products Emerging Dairy Processing Technologies (pp. 93-114): John Wiley \& Sons, Ltd.

Yang, B., Shi, Y., Xia, X., Xi, M., Wang, X., Ji, B., \& Meng, J., (2012). Inactivation of foodborne pathogens in raw milk using high hydrostatic pressure. Food Control, 28, 273-278.

Yao, J., Zhou, B., Wang, R., Wang, T., Hu, X., Liao, X., \& Zhang, Y., (2015). Inactivation of Staphylococcus aureus by high hydrostatic pressure in saline solution and meat slurry with different initial inoculum levels. Food and Bioproducts Processing, 94, 592-600. 


\section{Tables}

Table 1. Casein particle size $(\mu \mathrm{m})$ of raw, thermally treated and HPP milk samples after 0 and 7 days of storage at $4^{\circ} \mathrm{C}$.

\begin{tabular}{|l|l|l|l|l|}
\hline Day 0 & $\mathbf{d}(\mathbf{0 . 5})$ & $\mathbf{d}(\mathbf{0 . 9})$ & $\mathbf{D}[\mathbf{( 4 , 3 ) ]}$ & $\mathbf{D}[\mathbf{( 3 , 2 ) ]}$ \\
\hline Raw & $0.96 \pm 0.01^{\mathrm{b}}$ & $3.44 \pm 0.02^{\mathrm{b}}$ & $1.49 \pm 0.01^{\mathrm{b}}$ & $0.53 \pm 0.01^{\mathrm{a}}$ \\
\hline Thermal & $0.39 \pm 0.00^{\mathrm{c}}$ & $0.99 \pm 0.00^{\mathrm{c}}$ & $0.49 \pm 0.00^{\mathrm{c}}$ & $0.27 \pm 0.00^{\mathrm{b}}$ \\
\hline HPP & $1.21 \pm 0.19^{\mathrm{a}}$ & $4.05 \pm 0.21^{\mathrm{a}}$ & $2.15 \pm 0.15^{\mathrm{a}}$ & $0.54 \pm 0.14^{\mathrm{a}}$ \\
\hline Day 7 & $\mathbf{d}(\mathbf{0 . 5 )}$ & $\mathbf{d}(\mathbf{0 . 9})$ & $\mathbf{D}[\mathbf{( 4 , 3 ) ]}$ & $\mathbf{D}[(\mathbf{3 , 2})]$ \\
\hline Raw & $1.01 \pm 0.01^{\mathrm{b}}$ & $4.12 \pm 0.09^{\mathrm{a}}$ & $2.19 \pm 0.13^{\mathrm{a}}$ & $0.54 \pm 0.01^{\mathrm{b}}$ \\
\hline Thermal & $0.40 \pm 0.00^{\mathrm{c}}$ & $1.01 \pm 0.01^{\mathrm{c}}$ & $0.61 \pm 0.07^{\mathrm{c}}$ & $0.28 \pm 0.00^{\mathrm{c}}$ \\
\hline HPP & $1.17 \pm 0.01^{\mathrm{a}}$ & $3.72 \pm 0.04^{\mathrm{b}}$ & $1.67 \pm 0.01^{\mathrm{b}}$ & $0.71 \pm 0.00^{\mathrm{a}}$ \\
\hline
\end{tabular}

${ }^{\text {a-c }}$ Mean value \pm standard deviation; values without common superscripts were significantly different $(\mathrm{P}<0.05)$.

${ }^{*} \mathrm{D}(0.5)$ : diameter below which $50 \%$ of the volume of particles are found, $\mathrm{D}(0.9)$ : diameter below which $90 \%$ of the volume of particles are found, $\mathrm{D}[(4,3)]$ : volume-weighted mean diameter, $\mathrm{D}[(3,2)]$ : surface-weighted mean diameter. 
Table 2. Fat particle size $(\mu \mathrm{m})$ of raw, thermally treated and HPP milk samples after 0 and 7 days of storage at $4^{\circ} \mathrm{C}$.

\begin{tabular}{|l|l|l|l|l|}
\hline Day 0 & $\mathbf{d}(\mathbf{0 . 5})$ & $\mathbf{d}(\mathbf{0 . 9})$ & $\mathbf{D}[\mathbf{( 4 , 3 ) ]}$ & $\mathbf{D}[\mathbf{( 3 , 2 ) ]}$ \\
\hline Raw & $1.60 \pm 0.11^{\mathrm{b}}$ & $6.07 \pm 0.09^{\mathrm{b}}$ & $2.88 \pm 0.27^{\mathrm{b}}$ & $0.12 \pm 0.00^{\mathrm{a}}$ \\
\hline Thermal & $0.32 \pm 0.01^{\mathrm{a}}$ & $0.96 \pm 0.00^{\mathrm{a}}$ & $0.43 \pm 0.00^{\mathrm{a}}$ & $0.13 \pm 0.00^{\mathrm{a}}$ \\
\hline HPP & $3.26 \pm 0.42^{\mathrm{c}}$ & $7.50 \pm 0.36^{\mathrm{c}}$ & $4.79 \pm 0.91^{\mathrm{c}}$ & $0.27 \pm 0.14^{\mathrm{a}}$ \\
\hline Day 7 & $\mathbf{d}(\mathbf{0 . 5 )}$ & $\mathbf{d}(\mathbf{0 . 9})$ & $\mathbf{D}[\mathbf{( 4 , 3 ) ]}$ & $\mathbf{D}[(\mathbf{3 , 2})]$ \\
\hline Raw & $2.38 \pm 0.06^{\mathrm{b}}$ & $8.78 \pm 0.76^{\mathrm{a}}$ & $4.24 \pm 0.47^{\mathrm{a}}$ & $0.14 \pm 0.00^{\mathrm{a}}$ \\
\hline Thermal & $0.42 \pm 0.03^{\mathrm{c}}$ & $1.42 \pm 0.20^{\mathrm{b}}$ & $3.03 \pm 1.31^{\mathrm{a}}$ & $0.22 \pm 0.04^{\mathrm{a}}$ \\
\hline HPP & $3.19 \pm 0.29^{\mathrm{a}}$ & $8.57 \pm 2.19^{\mathrm{a}}$ & $5.62 \pm 1.51^{\mathrm{a}}$ & $0.23 \pm 0.06^{\mathrm{a}}$ \\
\hline
\end{tabular}

${ }_{\text {a-c }}$ Mean value \pm standard deviation; values without common superscripts were significantly different $(\mathrm{P}<0.05)$.

${ }^{*} \mathrm{~d}(0.5)$ : diameter below which $50 \%$ of the volume of particles are found, $\mathrm{d}(0.9)$ : diameter below which $90 \%$ of the volume of particles are found, $\mathrm{D}[(4,3)]$ : volume-weighted mean diameter, $\mathrm{D}[(3,2)]$ : surface-weighted mean diameter. 
Table 3. Distribution of the colour values of milk samples in CIE Lab system

\begin{tabular}{|l|l|l|l|}
\hline & $\mathrm{L}^{*}$ & $\mathrm{a}^{*}$ & $\mathrm{~b}^{*}$ \\
\hline HPP & $77.29 \pm 0.35^{\mathrm{c}}$ & $-0.61 \pm 0.08^{\mathrm{a}}$ & $14.03 \pm 0.30^{\mathrm{c}}$ \\
\hline Raw & $78.94 \pm 0.31^{\mathrm{b}}$ & $-0.34 \pm 0.05^{\mathrm{b}}$ & $12.49 \pm 0.26^{\mathrm{b}}$ \\
\hline Thermal & $80.80 \pm 0.32^{\mathrm{a}}$ & $-0.72 \pm 0.06^{\mathrm{a}}$ & $9.79 \pm 0.19^{\mathrm{a}}$ \\
\hline
\end{tabular}

${ }^{\text {a-c }}$ Mean value \pm standard deviation; values without common superscripts were significantly different $(\mathrm{P}<0.05)$. 


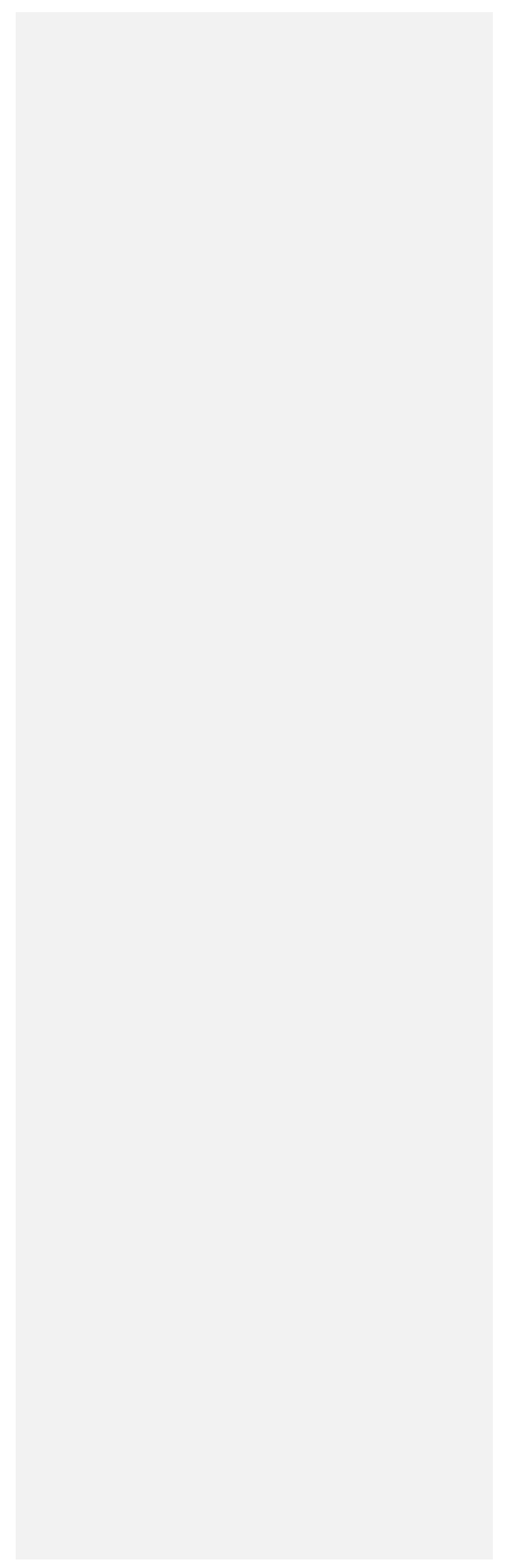




\section{Figures}

Figure 1

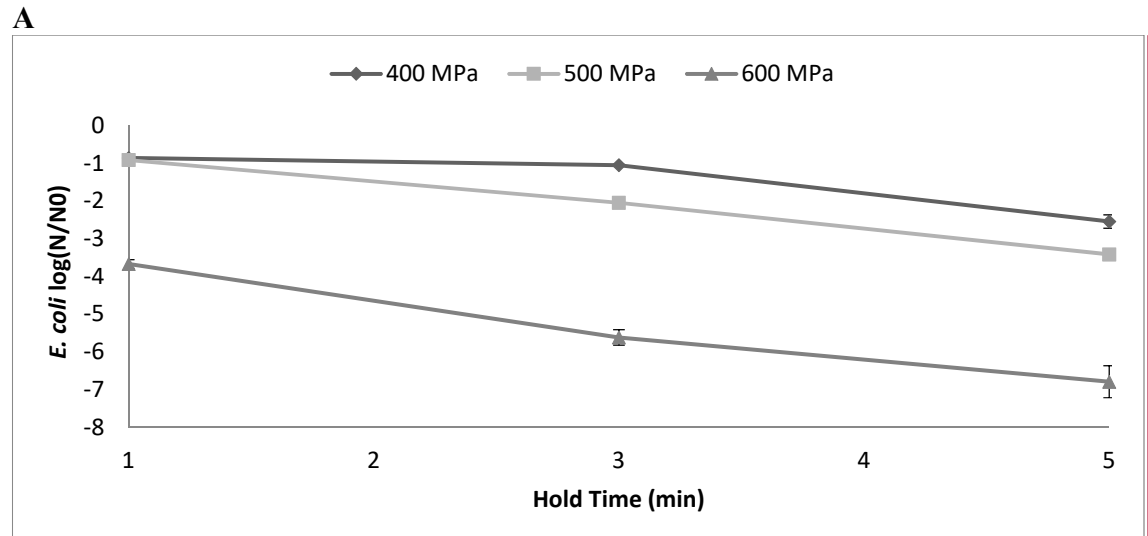

Commented [26]: Can these data sets be normalized?

B

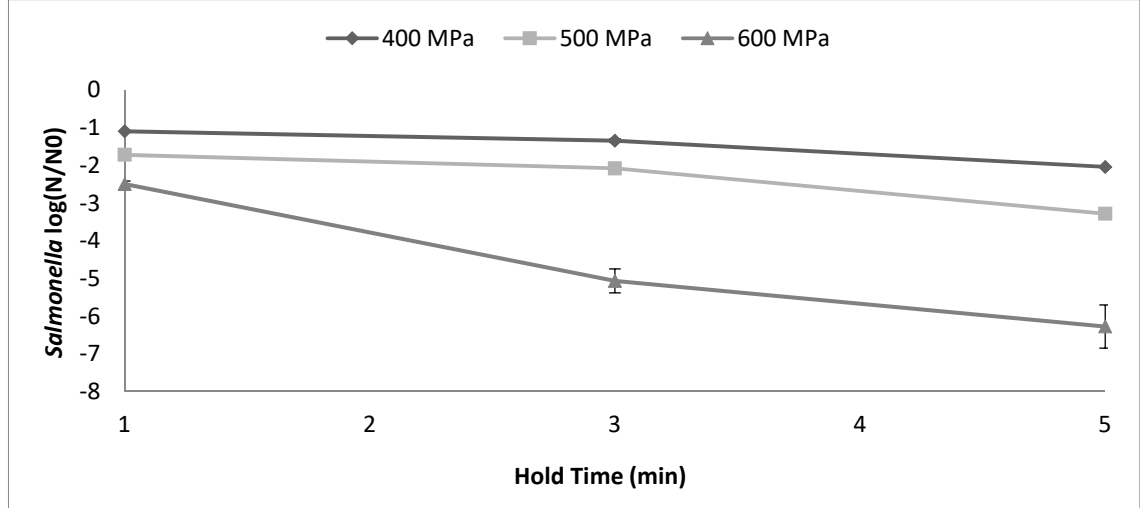

C

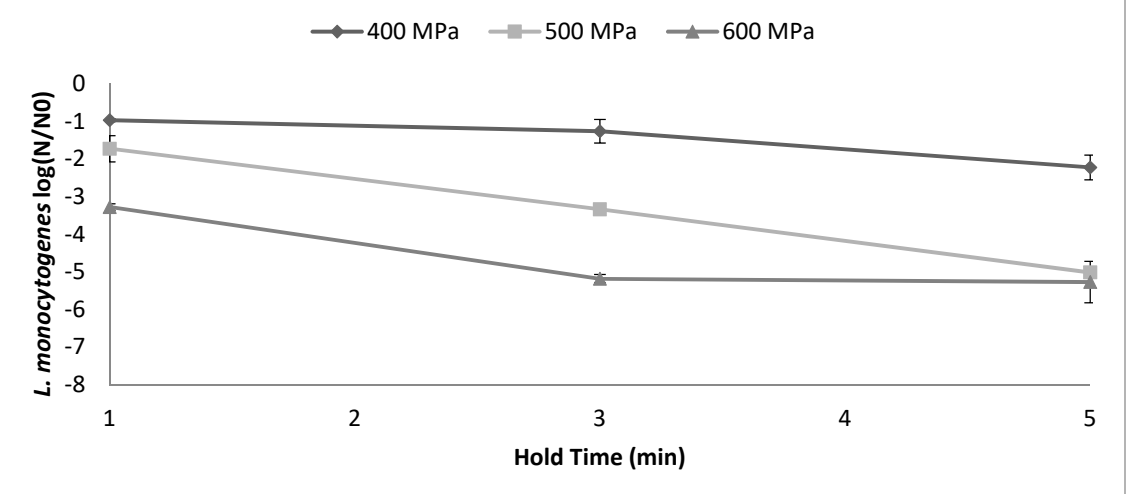


Figure 2

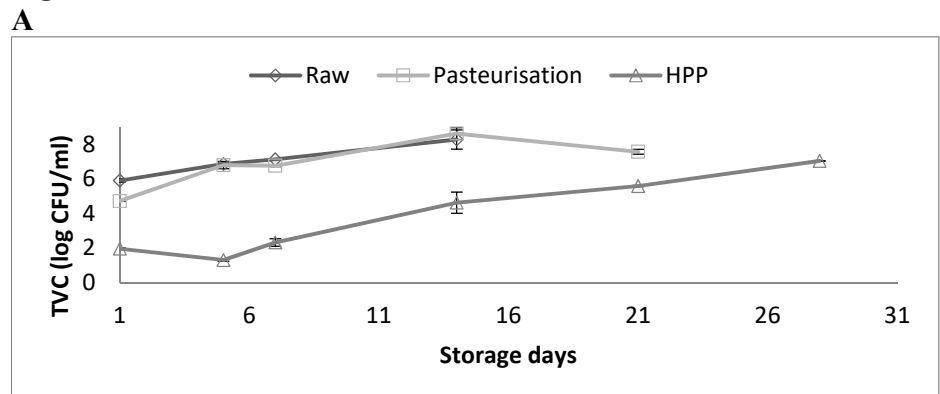

B

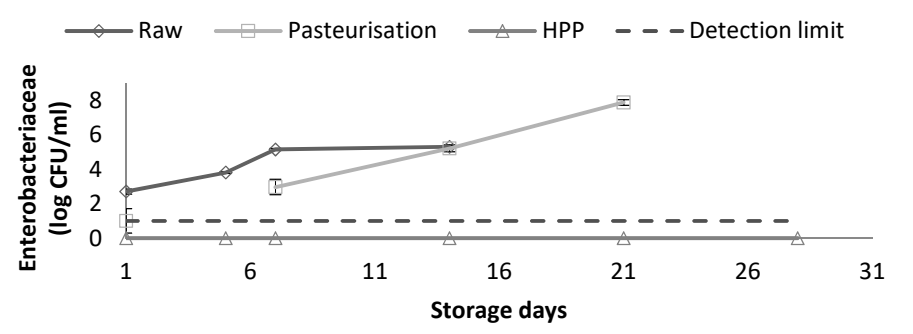

C

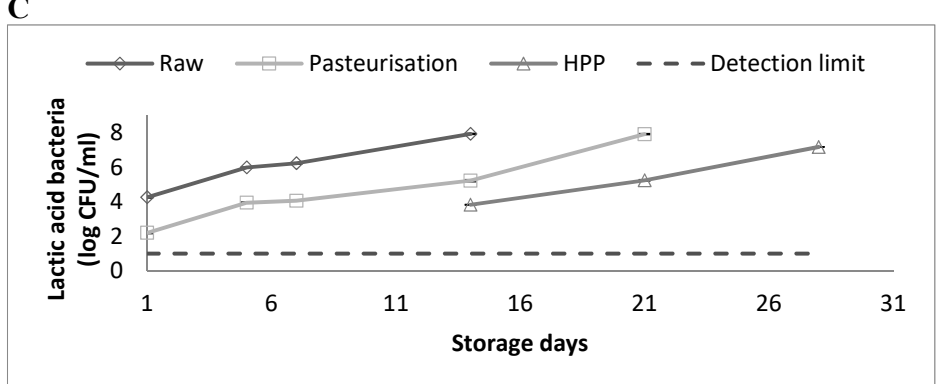

D

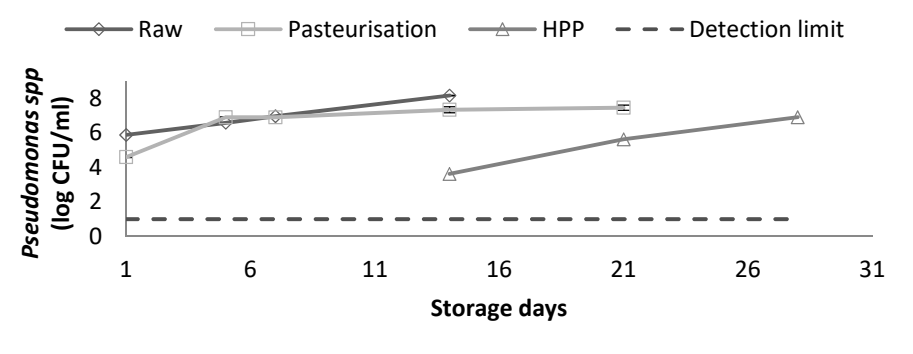


Figure 3
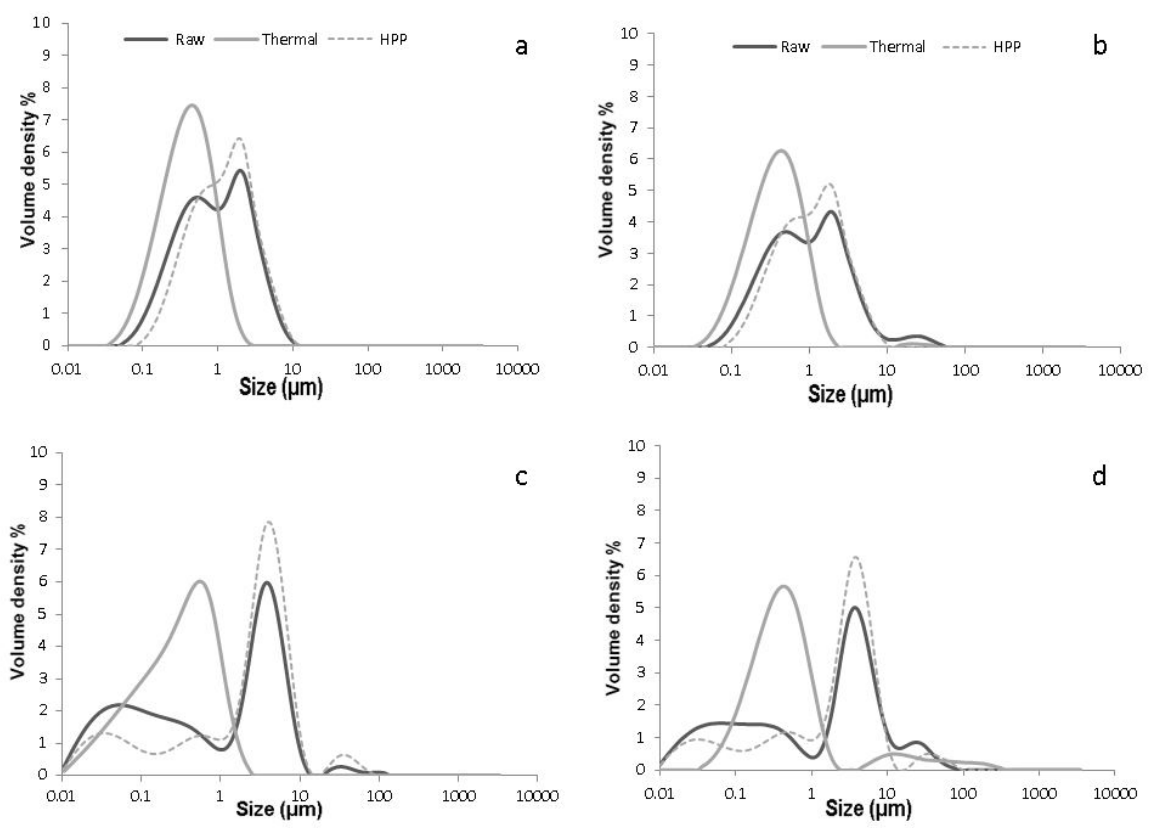